\title{
Comparative analysis of bed density, total phenol content and protein expression pattern in Posidonia oceanica (L.) Delile
}

\author{
Alice Rotini $^{1^{*}}$, Letizia Anello², Maria Di Bernardo ${ }^{2}$, Agata Giallongo $^{2}$, Luigi Valiante ${ }^{3}$, \\ Luciana Migliore ${ }^{1}$ \\ ${ }^{1}$ Dipartimento di Biologia, Università Tor Vergata, Rome, Italy; ${ }^{*}$ Corresponding Author: alice.rotini@gmail.com \\ ${ }^{2}$ Istituto di Biomedicina e Immunologia Molecolare, Consiglio Nazionale delle Ricerche, Palermo, Italy \\ ${ }^{3}$ ECON Sistemi Avanzati per l'Ambiente s.r.l., Naples, Italy
}

Received 25 September 2013; revised 23 October 2013; accepted 26 October 2013

Copyright (C) 2013 Alice Rotini et al. This is an open access article distributed under the Creative Commons Attribution License, which permits unrestricted use, distribution, and reproduction in any medium, provided the original work is properly cited.

\begin{abstract}
Posidonia oceanica meadows are experiencing a progressive decline, and monitoring their status is crucial for the maintenance of these ecosystems. We performed a comparative analysis of bed density, total phenol content and protein expression pattern to assess the conservation status of Posidonia plants from the S. Marinella (Rome, Italy) meadow. The total phenol content was inversely related to maximum bed density, confirming the relationship between high phenol content and stressful conditions. In addition, protein expression pattern profiles showed that the number of differentially expressed proteins was dramatically reduced in the latest years compared to previous analyses. Our results support the usefulness of integrating solid descriptors, such as phenol content, with novel biochemical/molecular approaches in the monitoring of meadows.
\end{abstract}

Keywords: Posidonia oceanica; Rhizome; Seagrass Monitoring; Total Phenols; 2-D Electrophoresis (2-DE); Bed Density; Protein Expression Pattern

\section{INTRODUCTION}

Posidonia oceanica (L.) Delile seagrass forms meadows which are widely recognized as key ecosystems in coastal habitats of the Mediterranean Sea [1]. Many authors have reported a regression of $P$. oceanica meadows, primarily due to human-induced disturbances [2-7]; as a consequence, several traditional, biochemical and molecular descriptors have been developed and applied to obtaining an integrated picture of their response to disturbances [8-14].

Plants under stressed conditions usually activate a series of physiological responses to minimize damage [15]. The numerous compounds that plants produce during their adaptive responses may be used as biomarkers. The relationship between phenol content and disturbance has been previously observed in several Posidonia meadows exposed to different environmental pressures, e.g., turbidity and pollution $[12,13,16]$, ocean acidification $[17$, 18], competition with invasive seaweed [19], and metal contamination [20].

Plant stress response and acclimation to stress are dynamic processes, mediated by profound changes in plant metabolism which are also mirrored at the proteomic level [21]. The proteomic approach, based on two dimensional electrophoresis (2-DE), permits the comparative analysis of quantitative and qualitative changes in protein expression patterns. The comparison of proteomic maps has been applied to several marine organisms to assess changes in protein profiles in response to different environmental conditions [22-27]. Differential protein expression analysis is commonly used to point out differences between proteomes of non-stressed (control) plants and those of stressed plants [21]. We previously observed a relationship between phenol content and protein expression patterns in $P$. oceanica rhizomes under different stress conditions [16].

Here, we present a comparative analysis of bed density, total phenol content and protein expression pattern to assess the conservation status of Posidonia meadows. 


\section{MATERIAL AND METHODS}

\subsection{Study Site and Sampling}

The study was conducted on the Santa Marinella (Rome, Italy) P. oceanica meadow, a Site of Community Importance (according to Habitat Directive 92/43/EEC). The main features and conservation status of the meadow and impacts along the sea stretch have been previously described [12]. The meadow was surveyed from 2005 to 2009.

For this study, P. oceanica plants were sampled by SCUBA divers at 20 stations in 2008 and 2009. The coordinates, depth and substratum of each sampling station are reported in Table 1.

A random sampling design was used; at least 3 orthotropic shoots were collected from each station. Immediately after sampling, plants were washed with distilled water and rhizomes cleaned with a blade to remove sheets and cortical tissues. Clean rhizomes were frozen

Table 1. Coordinates, depth and substratum $(\mathrm{M}=$ matte; $\mathrm{S}=$ sand) of each sampling station in the $P$. oceanica meadow of Santa Marinella (Rome, Italy).

\begin{tabular}{|c|c|c|c|c|}
\hline \multirow{2}{*}{$\begin{array}{l}\text { Sampling } \\
\text { Station }\end{array}$} & \multicolumn{2}{|c|}{ Coordinates UTM/ED50 } & \multirow{2}{*}{ Depth (m) } & \multirow{2}{*}{ Substratum } \\
\hline & East & North & & \\
\hline 1 & 740,006 & $4,657,987$ & 8.5 & M \\
\hline 2 & 740,026 & $4,657,994$ & 8.5 & M \\
\hline 3 & 740,057 & $4,657,961$ & 10 & M-S \\
\hline 4 & 740,120 & $4,657,882$ & 13 & M \\
\hline 5 & 739,952 & $4,657,814$ & 14 & M-S \\
\hline 6 & 739,939 & $4,657,815$ & 13 & S-M \\
\hline 7 & 738,649 & $4,657,877$ & 9.5 & M \\
\hline 8 & 738,679 & $4,657,836$ & 10.5 & M-S \\
\hline 9 & 738,644 & $4,657,838$ & 10.5 & $\mathrm{~S}$ \\
\hline 10 & 738,743 & $4,657,829$ & 10.5 & M \\
\hline 11 & 738,756 & $4,657,842$ & 10 & M \\
\hline 12 & 738,777 & $4,657,960$ & 8.5 & $\mathrm{~S}$ \\
\hline 13 & 738,782 & $4,657,998$ & 8 & $\mathrm{~S}$ \\
\hline 14 & 738,928 & $4,657,960$ & 9 & M-S \\
\hline 15 & 738,901 & $4,657,946$ & 9 & M-S \\
\hline 16 & 739,268 & $4,658,009$ & 9 & $\mathrm{~S}$ \\
\hline 17 & 738,523 & $4,657,754$ & 12 & $\mathrm{~S}$ \\
\hline 18 & 738,575 & $4,657,757$ & 11.5 & M \\
\hline 19 & 738,593 & $4,657,769$ & 12 & $\mathrm{~S}$ \\
\hline 20 & 738,649 & $4,657,775$ & 11 & M \\
\hline
\end{tabular}

in liquid nitrogen and then stored at $-80^{\circ} \mathrm{C}$ until processing.

\subsection{Bed Density}

During the five-year survey (2005-2009), bed density was evaluated in situ by counting the number of shoots using $40 \times 40 \mathrm{~cm}$ standard quadrats and recording five measurements at each station. The values obtained are reported as number of shoots/square meter $\left(\mathrm{m}^{2}\right)$.

\subsection{Total Phenol Content}

Total phenols were quantified in rhizomes from the three orthotropic shoots sampled at each site, according to Migliore et al. [16]. Two extractions were done for each sample, and all the extracts were read in duplicate. Final results were expressed as milligrams of phenolic compounds per gram of rhizome fresh weight, and they are the arithmetic means of four measurements. Based on their phenol concentration and total protein content (determined by the Bradford assay), four shoots from each sampling year (2008 and 2009) were chosen for protein expression pattern analysis. The selected shoots were those with the highest ( 2 shoots) and the lowest ( 2 shoots) phenol content in the basal portion of the rhizome. Only shoots yielding comparable amounts of total proteins were selected.

\section{Statistical Analysis}

For density and total phenol content, the differences among years were analysed through ANOVA. Levene's test was used for testing the homogeneity of group variances and post-hoc comparisons of means were performed through Tukey's test. Kruskall-Wallis ANOVA multiple comparison test and Mann-Whitney U test were used when data did not satisfy the homoscedasticity assumptions (Levene's test).

\subsection{Protein Analysis by 2-DE}

For each annual batch, $250 \mathrm{mg}$ of the basal rhizome section from the four selected shoots were used for protein extraction. Total proteins were extracted according to Wang et al. [28], as modified for P. oceanica rhizomes [16], and protein concentration was determined by the Bradford assay (Biorad). Protein samples $(12 \mu \mathrm{g})$ were applied in $155 \mu \mathrm{l}$ of 2-DE rehydration solution ( $8 \mathrm{M}$ Urea, $2 \mathrm{M}$ Thiourea, 2\% CHAPS, $50 \mathrm{mM}$ DTT, $0.2 \%$ Anfoline (Bio-Lyte BIORAD), protease and phosphatase inhibitors (SIGMA) to $7 \mathrm{~cm}$ Readystrip IPG (Immobilized pH Gradient, $\mathrm{pH}$ 3-10NL, Bio-Rad Laboratories), by incubating overnight. Isoelectrofocusing (IEF) was performed at room temperature using the ZOOM IPG RunnerTM Mini-cell (Invitrogen), applying $175 \mathrm{~V}$ for 15 $\mathrm{min}, 175-2000 \mathrm{~V}$ for $45 \mathrm{~min}$ and $2000 \mathrm{~V}$ for $30 \mathrm{~min}$. 
Focused strips were equilibrated using DTT and iodoacetamide solutions and subjected to protein separation by second dimension electrophoresis.

Electrophoresis was performed using Precast Gradient Gels (NuPAGE 4\% - 12\% acrylamide, Life Technologies) at $80 \mathrm{~V}$ in running Buffer MOPS-SDS $1 \mathrm{X}$, according to standard procedures. Proteome isoelectric point $(\mathrm{p} I)$ markers were from SERVA Electrophoresis (Heidelberg), and molecular weight (MW) markers were from New England Biolabs. Each protein sample was subjected to at least 2 parallel runs of isolectrofocusing and second dimension electrophoretic separation to assess proteomic pattern reproducibility. Protein spots were visualized by acidic silver staining.

\section{Image Processing and Data Analysis}

Gel scan images were acquired, generating $6.2 \mathrm{Mb}$ Tiff format images, then imported into the PDQuest 2-D Analysis Software (Biorad, version 8.0.1).

Spots were automatically detected on the basis of prechosen spot parameters, such as the faintest, the smallest and the largest spot. Other parameters (such as sensitivity, minimal peak value, size scale) were adjusted and background noise subtracted to selectively identify true spots. To attribute $\mathrm{p} I$ and relative molecular weight (MW), a mixture of five proteins of known identity was used as an internal standard.

In order to detect proteins selectively expressed in high-phenol and low-phenol plants, a comparative analysis was performed using PDQuest Analysis Software: two low-phenol and two high-phenol gel scans per year were matched. Only well-resolved spots were taken into account, discarding streaked and edge areas. Only the spots present in the gels of one set but absent from the other were taken into account and regarded as specific. All spots were considered and double-checked for accuracy.

\section{RESULTS}

\subsection{Bed Density}

The bed density in the S. Marinella meadow from 2005 to 2009 is reported in Figure 1 as a box plot; mean values ( \pm S.D.) varied between $367.1 \pm 110.3$ (2005) and $281.6 \pm 76.6$ and $283.8 \pm 105.2$ shoots $/ \mathrm{m}^{2}$ (2007 and 2009 , respectively). The Kruskall-Wallis test for independent variables did not highlight differences among years (not significant, n.s.). Nevertheless, the box plots show 1) a clear increase of the interquartile range (IQR, i.e., the difference between the upper and lower quartiles), except in 2007, and 2) a reduction of the maximum bed density in the meadow $(\mathrm{Q} 4$, i.e., the highest density value registered each year among all the sam-

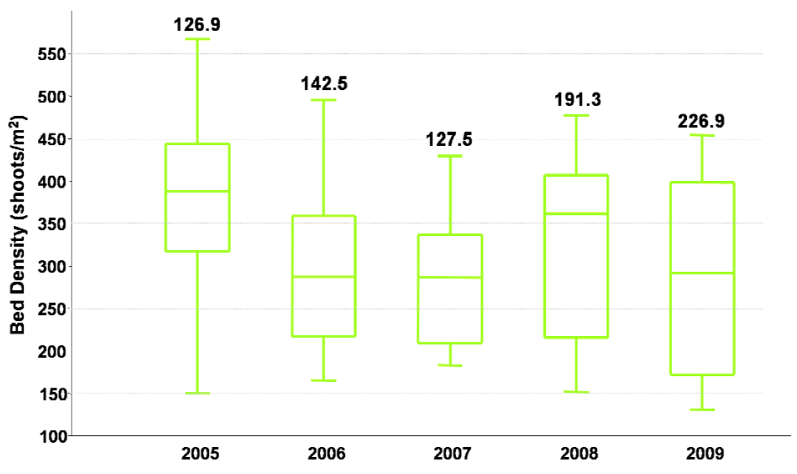

Figure 1. Bed density in the S. Marinella $P$. oceanica meadow from 2005 to 2009 , represented as box-plots. The box plot contains $50 \%$ data (the extremes of the box are the Q1 and Q3, $1^{\text {st }}$ and $3^{\text {rd }}$ quartiles), the internal horizontal segments represent the median of the distributions (Q2 value, $2^{\text {nd }}$ quartile), "whiskers" range from the lowest to the highest value; the interquartile range value is reported (IQR $=\mathrm{Q} 3-\mathrm{Q} 1)$ on the top of each box-plot.

pling stations).

\subsection{Total Phenol Content}

The mean total phenol content in the $P$. oceanica rhizomes collected in 2008 and 2009 was $27.6 \pm 5.4 \mathrm{mg} / \mathrm{g}$ and $28.4 \pm 4.6 \mathrm{mg} / \mathrm{g}$, respectively. The mean phenol content in each rhizome section is reported in Table 2. The differences between the two years and among rhizome sections were not statistically significant (two-way ANOVA, n.s.).

\subsection{Protein Analysis by 2-D Electrophoresis}

The expression pattern of $P$. oceanica rhizomes from the 2008 and 2009 samples was obtained by 2-D electrophoresis. Two representative 2-D gels from low and high phenols are shown in Figure 2. Protein maps showed a similar spatial arrangement of protein spots and a comparable total number of spots (495 in 2008 and 472 in 2009). Furthermore, computer-assisted analysis of the 2-D gel profile confirmed the presence of protein spots which were exclusively expressed in the plants with the higher or lower phenol contents. A total of nine specific spots were found in the high phenol plants in both 2008 and 2009; four and six specific spots were found in the low phenol plants in 2008 and 2009, respectively (Table 3).

\section{DISCUSSION}

In the present study, the bed density, total phenol content and protein expression pattern were evaluated in $P$. oceanica plants from the S. Marinella meadow. The role and interaction of the different descriptors are discussed below. 
Table 2. Mean $( \pm$ S.D.) phenol content in P. oceanica rhizome sections of plants collected in 2008 and 2009. Phenol content is expressed as $\mathrm{mg} / \mathrm{g}$ fresh weight (f.w.).

\begin{tabular}{cccc}
\hline \multirow{2}{*}{ Sampling year } & \multicolumn{3}{c}{ Rhizome section } \\
\cline { 2 - 4 } & Apical & Interm. & Basal \\
\hline 2008 & $28.5 \pm 4.7$ & $28.0 \pm 5.5$ & $26.2 \pm 6.0$ \\
2009 & $28.9 \pm 4.3$ & $28.1 \pm 5.1$ & $28.0 \pm 4.6$ \\
\hline
\end{tabular}

Table 3. Specific protein spots identified in the 2-DE maps of low- and high-phenol P. oceanica rhizomes, collected in 2008 and 2009. The experimental values of isoelectric point $(\mathrm{p} I)$ and molecular weight (MW) were calculated using the PDQuest 2-D Analysis Software.

\begin{tabular}{|c|c|c|c|}
\hline \multirow{2}{*}{ Year } & \multicolumn{3}{|c|}{ High phenol spots } \\
\hline & Spot & $\mathrm{p} I$ & MW \\
\hline \multirow{9}{*}{2008} & H1 08 & 5.96 & 79.2 \\
\hline & H2 08 & 6.04 & 35.85 \\
\hline & H3 08 & 6.05 & 48.77 \\
\hline & H4 08 & 6.23 & 77.32 \\
\hline & H5 08 & 6.5 & 77.69 \\
\hline & H6 08 & 6.43 & 132.16 \\
\hline & H7 08 & 7.22 & 126.93 \\
\hline & H8 08 & 7.33 & 79.68 \\
\hline & H9 08 & 7.98 & 82.75 \\
\hline \multirow{9}{*}{2009} & H1 09 & 4.88 & 22.04 \\
\hline & H2 09 & 4.93 & 33.47 \\
\hline & Н3 09 & 5.05 & 28.59 \\
\hline & H4 09 & 5.12 & 110.43 \\
\hline & H5 09 & 5.36 & 71.43 \\
\hline & H6 09 & 5.42 & 84.53 \\
\hline & H7 09 & 5.31 & 94.59 \\
\hline & H8 09 & 5.69 & 80.35 \\
\hline & H9 09 & 7.73 & 16.94 \\
\hline \multirow{3}{*}{ Year } & & henol & \\
\hline & Spot & $\mathrm{p} I$ & MW \\
\hline & L1 08 & 6.26 & 49.19 \\
\hline \multirow{3}{*}{2008} & L2 08 & 7.24 & 111.21 \\
\hline & L3 08 & 7.71 & 45.78 \\
\hline & L4 08 & 8.94 & 44.56 \\
\hline \multirow{6}{*}{2009} & L1 09 & n.d. & 27.6 \\
\hline & L2 09 & 4.77 & 66.29 \\
\hline & L3 09 & 4.98 & 63.21 \\
\hline & L4 09 & 5.53 & 84.27 \\
\hline & L5 09 & 5.79 & 55.91 \\
\hline & L6 09 & n.d. & 30.94 \\
\hline
\end{tabular}

\subsection{Bed Density and Total Phenol Content}

During the five-year survey, the mean bed density fluctuated between "sparse bed" and "very sparse bed", according to Giraud [29] as modified by Pergent et al. [30]. Due to the high variability of density values in both time and space, no significant regressive trend can be inferred. However, the increase of the spatial variability and the gradual decrease in maximum bed density during the 2005-2009 period are indications of the regressive process. In fact, an increasing patchiness of the meadow is a common feature of the regressive process in Posidonia meadows [31]. This reflects the frequency and magnitude of disturbances which are factors preventing seagrasses from reaching their maximum potential abundance [32].

The total phenol content in P. oceanica rhizomes did not show significant variations between the two years. Values are far higher than those previously found in the S. Marinella meadows since $2004[12,16]$. Putting together these total phenol content data, an increasing trend over time (2005-2009) can be highlighted. When the mean total phenol content is plotted against the maximum bed density from 2005 to 2009 , an inverse relationship between these two descriptors is clearly found (Figure 3).

The relationship between phenol content and stressful conditions has been previously shown in seagrasses [12, $13,16,18-20,33]$. Thus, the inverse relationship between total phenol content and maximum bed density in the S. Marinella meadow strongly supports the hypothesis of the ongoing regressive process in this meadow. The meadow regression can be partially related to the increasing environmental pressure on this stretch of sea which has occurred in recent years [34].

\subsection{Protein Analysis by 2-DE and Total Phenol Content}

The expression pattern of $P$. oceanica rhizomes from the 2008 and 2009 samples is comparable in terms of total spot number and the number of spots exclusively expressed in plants with higher or lower phenol contents. When compared to 2006 samples [16], the 2008-2009 protein maps show similar total spot number and spatial arrangement. However, there is an evident difference between the 2006 and 2008-2009 protein expression profiles: the number of differentially expressed proteins is dramatically reduced in the 2008-2009 samples (Table 4).

As the increase in phenol content marks the stressful condition and the reduction of the conservation status of the S. Marinella meadow [12], the lower variability observed in protein expression could be related to plant stress response.

Thus, the differentially expressed proteins can be po- 

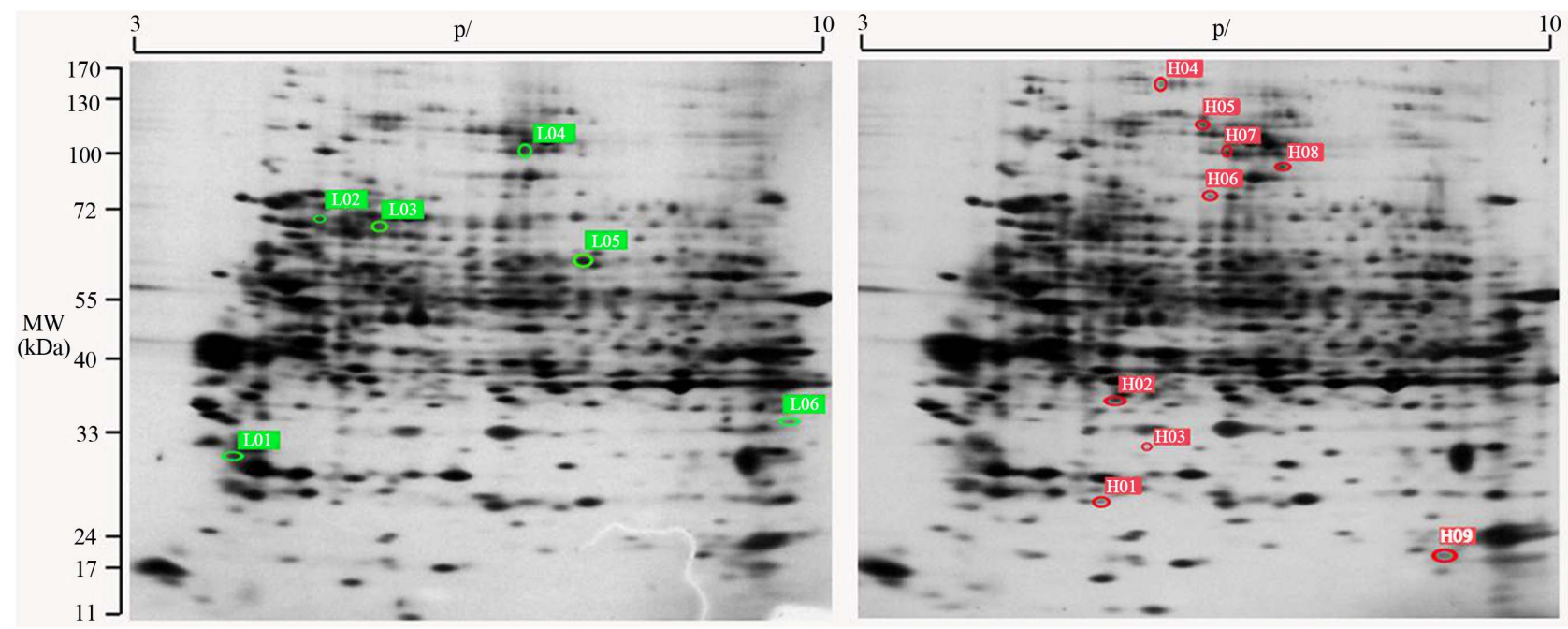

Figure 2. Representative 2-DE gels from $P$. oceanica plants with low (A) or high (B) total phenol content (2009 samples). Each specific protein spot exclusively expressed in the low or high phenol samples is highlighted with green or red ellipses and labeled (L\# or H\# according to Table 2).

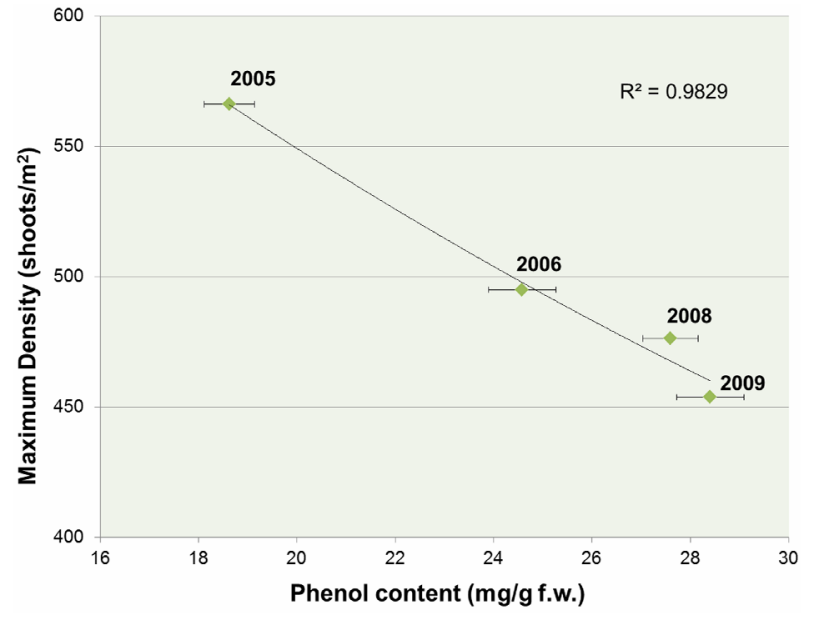

Figure 3. Relationship between total phenol content and maximum shoot density in S. Marinella $P$. oceanica meadow from 2005 to 2009 (error bars indicate standard deviation). The significant correlation appears linear $(\mathrm{r}=-0.99$, $\mathrm{p}$ (uncorr) $<0.01)$.

Table 4. Comparison of protein expression pattern analyses performed on 2006, 2008 and 2009 P. oceanica rhizomes (basal section). For each year, the number of total and differentially expressed spots and maximum and minimum phenol content recorded in rhizomes are reported.

\begin{tabular}{cccc}
\hline & $\mathbf{2 0 0 6}$ & $\mathbf{2 0 0 8}$ & $\mathbf{2 0 0 9}$ \\
\hline Total spots expressed & 437 & 495 & 472 \\
High phenols spots & 27 & 9 & 9 \\
Low phenols spots & 22 & 4 & 6 \\
$\begin{array}{c}\text { Min-Max phenol content } \\
\text { (mg/g f.w.) }\end{array}$ & $6.8-35.0$ & $14.3-35.8$ & $15.8-32.9$ \\
\hline
\end{tabular}

tential protein biomarkers of stress and/or health conditions of $P$. oceanica meadows. Further investigations can significantly contribute to their identification and characterization.

In conclusion, this study contributes towards the setting up of a multidisciplinary approach for seagrass monitoring. The punctual response of total phenol to stress conditions supports its feasibility as an early warning indicator. Furthermore, the study of plant response to stress at the protein level can significantly improve our understanding of the physiological mechanisms underlying plant stress response and/or tolerance.

The set up of novel (possibly early-warning) indicators of seagrass health is necessary to prevent further seagrass loss. The proteomic approach could help to identify potential protein biomarkers of stress and/or healthy conditions in $P$. oceanica meadows.

To date, the ecological status of P. oceanica has usually been assessed by quantifying shoot densities, biomass or growth rates; however, these descriptors cannot fully describe the plant physiology and/or predict the persistence of seagrass meadows. The use of biochemical/protein markers may improve meadow monitoring and reduce costly and time consuming field activities.

\section{ACKNOWLEDGEMENTS}

Special thanks are due to Patrizia Rubino for her excellent technical assistance and to Flora Carannante for her support in the sampling activities. The authors are also grateful to Richard Burket and Astrid Mejia, who kindly revised and edited the manuscript.

This work was supported by the Consiglio Nazionale delle Ricerche/Ministero dell'Università e Ricerca (National Research Council/Ministry of University and Research). This work was also supported by an RFO (Ricerca Fondamentale Orientata) grant from the University 
of Tor Vergata to LM.

\section{REFERENCES}

[1] Hemminga, M. and Duarte, C.M. (2000) Seagrass ecology. Cambridge University Press, Cambridge. http://dx.doi.org/10.1017/CBO9780511525551

[2] Apostolaki, E.T., Marbà N., Holmer, M. and Karakassis, I. (2009) Fish farming enhances biomass and nutrient loss in Posidonia oceanica (L.) Delile. Estuarine and Coastal Shelf Science, 81, 390-400. http://dx.doi.org/10.1016/j.ecss.2008.11.014

[3] Balestri, E., Benedetti-Cecchi, L. and Lardicci, C. (2004) Variability in patterns of growth and morphology of Posidonia oceanica exposed to urban and industrial wastes: Contrasts with two reference locations. Journal of Experimental Marine Biology and Ecology, 308, 1-21. http://dx.doi.org/10.1016/j.jembe.2004.01.015

[4] Marbà, N. and Duarte, C.M. (2010) Mediterranean warming triggers seagrass (Posidonia oceanica) shoot mortality. Global Change Biology, 16, 2366-2375. http://dx.doi.org/10.1111/j.1365-2486.2009.02130.x

[5] Marbà, N., Duarte, C.M., Díaz-Almela, E., Terrados, J., Álvarez, E., Martínez, R., Santiago, R., Gacia, E. and Grau, A.M. (2005) Direct evidence of imbalanced seagrass (Posidonia oceanica) shoot population dynamics in the Spanish Mediterranean. Estuaries, 28, 53-62. http://dx.doi.org/10.1007/BF02732753

[6] Montefalcone, M., Chiantore, M., Lanzone, A., Morri, C., Bianchi, C.N. and Albertelli, G. (2008) BACI design reveals the decline of the seagrass Posidonia oceanica induced by anchoring. Marine Pollution Bulletin, 56, 16371645. http://dx.doi.org/10.1016/j.marpolbul.2008.05.013

[7] Ruiz, J.M. and Romero, J. (2003) Effects of disturbances caused by coastal constructions on spatial structure, growth dynamics and photosynthesis of the seagrass Posidonia oceanica. Marine Pollution Bulletin, 46, 15231533. http://dx.doi.org/10.1016/j.marpolbul.2003.08.021

[8] Boudouresque, C.F., Bernard, G., Bonhomme, P., Charbonnel, E., Diviacco, G., Meinesz, A., Pergent, G., Pergent-Martini, C., Ruitton, S. and Tunesi, L. (2006) Préservation et conservation des herbiers à Posidonia oceanica. RaMoGe Publication, Monaco.

[9] Ferrat, L., Pergent-Martini, C. and Roméo, M. (2003) Assessment of the use of biomarkers in aquatic plants for the evaluation of environmental quality: Application to seagrasses. Aquatic Toxicology, 65, 187-204. http://dx.doi.org/10.1016/S0166-445X(03)00133-4

[10] Mazzuca, S., Björk, M., Beer, S., Felisberto, P., Gobert, S., Procaccini, G., et al. (2013) Establishing research strategies, methodologies and technologies to link genomics and proteomics to seagrass productivity, community metabolism, and ecosystem carbon fluxes. Frontiers in Plant Science, 4, 1-19.

http://dx.doi.org/10.3389/fpls.2013.00038

[11] Procaccini, G., Olsen, J.L. and Reusch, T.B.H. (2007) Contribution of genetics and genomics to seagrass biology and conservation. Journal of Experimental Marine Biology and Ecology, 350, 234-259. http://dx.doi.org/10.1016/j.jembe.2007.05.035

[12] Rotini, A., Micheli, C., Valiante, L. and Migliore, L. (2011) Assessment of Posidonia oceanica (L.) Delile conservation status by standard and putative approaches: The case study of Santa Marinella meadow (Italy, W Mediterranean). Open Journal of Ecology, 1, 48-56. http://dx.doi.org/10.4236/oje.2011.12006

[13] Rotini, A., Belmonte, A., Barrote, I., Micheli, C., Peirano, A., Santos, R.O., Silva, J. and Migliore, L. (2013) Effectiveness and consistency of a suite of descriptors to assess the ecological status of seagrass meadows (Posidonia oceanica L. Delile). Estuarine, Coastal and Shelf Science, 130, 252-259.

http://dx.doi.org/10.1016/j.ecss.2013.06.015

[14] Silva, J., Sharon, Y., Santos, R. and Beer, S. (2009) Measuring seagrass photosynthesis: Methods and applications. Aquatic Biology, 7, 127-141.

http://dx.doi.org/10.3354/ab00173

[15] Orcutt, D.M., Nilsen, E.T. and Hale, M.G. (2000) The physiology of plants under stress: Soil and biotic factors. John Wiley \& Sons, Inc., Hoboken.

[16] Migliore, L., Rotini, A., Randazzo, D., Albanese, N. and Giallongo, A. (2007) Phenols content and 2-D electrophoresis protein pattern: A promising tool to monitor Posidonia meadows health state. BMC Ecology, 7, 6. http://dx.doi.org/10.1186/1472-6785-7-6

[17] Migliore, L., Piccenna, A., Rotini, A., Garrard, S. and Buia, M.C. (2012) Can ocean acidification affect chemical defenses in Posidonia oceanica? Proceeding of the 3rd Mediterranean Seagrass Workshop, Essaouira, 14. http://cmsdata.iucn.org/downloads/proceedings of the $\mathrm{m}$ editerranean_seagrass_workshop_20121.pdf

[18] Arnold, T., Mealey, C., Leahey, H., Miller, A.W., HallSpencer, J.M., Milazzo, M. and Maers, K. (2012) Ocean acidification and the loss of phenolic substances in marine plants. PLoS One, 7, e35107. http://dx.doi.org/10.1371/journal.pone.0035107

[19] Pergent, G., Boudouresque, C.F., Dumay, O., PergentMartini, C. and Wyllie-Echeverria, S. (2008) Competition between the invasive macrophyte Caulerpa taxifolia and the seagrass Posidonia oceanica: Contrasting strategies. BMC Ecology, 8, 20. http://dx.doi.org/10.1186/1472-6785-8-20

[20] Ferrat, L., Pergent-Martini, C., Romeo, M. and Pergent, G. (2003) Hydrosoluble phenolic compounds production in a Mediterranean seagrass according to mercury contamination. Gulf of Mexico Science Journal, 21, 108.

[21] Kosová, K., Vítámvás, P., Prášil, I.T. and Renaut J. (2011) Plant proteome changes under abiotic stress-Contribution of proteomics studies to under standing plant stress response. Journal of Proteomics, 74, 1301-1322. http://dx.doi.org/10.1016/j.jprot.2011.02.006

[22] Andacht, T.M. and Winn, R.N. (2006) Incorporating proteomics into aquatic toxicology. Abstract from 13th International Symposium on Pollutant Responses in Marine Organisms. Marin Environmental Research, 62, 156-157.

[23] Kim, Y.K., Yoo, W.I., Lee, S.H. and Lee, M.Y. (2005) Proteomic analysis of cadmium-induced protein profile alterations from the marine alga Nannochloropsis oculata. 
Ecotoxicology, 14, 589-596. http://dx.doi.org/10.1007/s10646-005-0009-5

[24] Lopez, J.L. (2007) Applications of proteomics in marine ecology. Marine Ecology Progress Series, 332, 275-279. http://dx.doi.org/10.3354/meps332275

[25] Matranga, V., Pinsino, A., Randazzo, D., Giallongo, A. and Dubois, P. (2012) Long-term environmental exposure to metals $(\mathrm{Cu}, \mathrm{Cd}, \mathrm{Pb}, \mathrm{Zn})$ activates the immune cell stress response in the common European sea star (Asterias rubens). Marine Environmental Research, 76, 122127. http://dx.doi.org/10.1016/j.marenvres.2011.09.008

[26] Nunn, B.L. and Timperman, A.T. (2007) Marine proteomics. Marine Ecology Progress Series, 332, 281-289. http://dx.doi.org/10.3354/meps332281

[27] Tomanek, L. (2011) Environmental proteomics: Changes in the proteome of marine organisms in response to environmental stress, pollutants, infection, symbiosis, and development. Annual Review of Marine Science, 3, 373399.

[28] Wang, W., Vignani, R., Cresti, M. and Scali, M. (2006) A universal and rapid protocol for protein extraction from recalcitrant plant tissues for proteomic analysis. Electrophoresis, 27, 2782-2786. http://dx.doi.org/10.1002/elps.200500722

[29] Giraud, G. (1977) Essai de classement des herbiers de Posidonia oceanica (L.) Delile. Botanica Marina, 20,
487-491. http://dx.doi.org/10.1515/botm.1977.20.8.487

[30] Pergent, G., Pergent-Martini, C. and Boudouresque, C.F. (1995) Utilisation de l'herbier à Posidonia oceanica comme indicateur biologique de la qualité du milieu littoral en Méditerranée: Etat des connaissances. Mesogée, 54, 3-29.

[31] Tigny, V., Ozer, A., De Falco, G., Baroli, M. and Djenidi, S. (2007) Relationship between the evolution of the shoreline and the Posidonia oceanica meadow limit in a Sardinian coastal zone. Journal of Coastal Research, 23, 787-793. http://dx.doi.org/10.2112/05-0472.1

[32] Duarte, C.M., Fourqurean, J.W., Krause-Jensen, D. and Olesen, B. (2006) Dynamics of seagrass stability and change. In: Larkum, A.W.D., Orth, R.G. and Duarte, C.M., Eds., Seagrasses: Biology, Ecology and Conservation, Springer Press, The Netherlands, 271-294.

[33] Vergeer, L.H.T. and Develi, A. (1997) Phenolic acids in healthy and infected leaves of Zostera marina and their growth-limiting properties towards Labyrinthula zosterae. Aquatic Botany, 58, 65-72. http://dx.doi.org/10.1016/S0304-3770(96)01115-1

[34] Dante, G. (2010) Development of sustainable strategies for conservation and management of Posidonia oceanica, (Linneo) Delile 1813, meadow: A case study within a Site of Community Importance. Ph.D. Thesis, University of Tuscia, Viterbo. 